\title{
WELL-BEING AND EMIGRATION PLANS AMONG UNIVERSITY STUDENTS IN SLOVAKIA: THE MEDIATION EFFECT OF ROOTEDNESS
}

\author{
Frederika Lučanská ${ }^{1}$, Ol'ga Orosová $^{2}$, Marta Dobrowolska Kulanová ${ }^{2}$, \\ \& Lenka Abrinková ${ }^{1}$ \\ ${ }^{1}$ Department of Psychology, Faculty of Arts, PJ Safarik University in Kosice (Slovakia) \\ ${ }^{2}$ Department of Educational Psychology and Psychology of Health, Faculty of Arts, \\ PJ Safarik University in Kosice (Slovakia)
}

\begin{abstract}
Objective: The objective of this study was to examine the relationship between well-being, rootedness and emigration plans (EP) among university students in Slovakia. It also tested the mediation effect of rootedness in the relationship between well-being and EP.

Methods: The data for this study were collected via an online survey which was part of the Student Life Cohort Study (SLiCE 2016). The research sample consisted of 141 (86.5\% female) Slovak university students $(\mathrm{M}=22.5$ years, $\mathrm{SD}=2.8)$. EP were identified by one question with 8 answer options. Based on the answer, the respondents were divided into two groups; those who do not plan to leave Slovakia (54.6\%) and those who plan to leave in the long term (45.4\%). Rootedness was measured by the Rootedness scale which consists of the Desire for Change and Home/Family subscales. For the purposes of the current study, binary logistic regression was used in two steps. The Hayes' PROCESS tool explored the indirect effects of well-being on emigration plans through two dimensions of rootedness. All analyses were controlled for gender.

Results: Firstly, the relationship between well-being and EP was examined. As predicated, well-being $(\beta=-0.183, \mathrm{p}<0.001)$ was significantly associated with EP with higher well-being having a negative effect on EP. Next, rootedness was added to the model which explained $51.6 \%$ of the variance in emigration. Two dimensions of rootedness were found to make the largest contribution to explaining EP. A higher desire for change $(\beta=0.367, p<0.001)$ had a positive effect on EP while higher family rooting $(\beta=-0.240, p<0.05)$ had a negative effect on EP. Interestingly, well-being $(\beta=-0,072)$ was not shown to be a significant predictor of EP. These findings were also confirmed by the mediation analysis. The relationship between well-being and EP was negative, but not significant. The association between well-being and EP was fully mediated by two dimensions of rootedness with different psychological mechanisms. On one hand, the higher the well-being, the lower the desire for change and the lower the desire for change, the more likely it is that Slovak students will not plan to leave. On the other hand, the higher the well-being, the higher the family rootedness and the higher family rootedness, the more likely it is that Slovak students will not plan to leave.

Conclusion: This study contributes to the current knowledge regarding predictors of emigration plans among students.
\end{abstract}

Keywords: Emigration plans, well-being, rootedness, university students.

\section{Introduction}

Migration is a phenomenon of different causes and manifestations in the world and is currently taking on much larger proportions than it had in the past. However, migration is also not stable. This phenomenon naturally develops as the result of new and better modes of transport, the discovery of new technologies and the Internet. Slovakia has long been known as a country of origin of migrants. Even today's numbers remain quite high and 1863 residents left Slovakia in 2011 according to Káčerová \& Horváthová (2014). Three groups of inhabitants leave Slovakia most often: highly qualified individuals (who are unable to find work with adequate financial remuneration here), students and also retired people (Baláž, 2009). In terms of education, Slovakia loses many secondary school leavers and university graduates every year. In $2011,53.68 \%$ of those leaving Slovakia had secondary school education and 21.55\% had higher education (Káčerová \& Horváthová, 2014). In connection with this issue Haluš et al. (2017) have pointed out that Slovakia is facing both a demographic crisis and a significant brain drain due 
to young people leaving. Slovakia has lost 300,000 citizens since 2000, which represents about 5\% of the population. This number increases every year and more importantly is that more than half of these people are under the age of 30 . The authors also point out that approximately one in 10 students who have completed their education leave abroad. According to Sheikh et al. (2012), only $24 \%$ of young students are willing to consider their decision to go abroad. Brahna (2009) described the profile of a Slovak migrant based on previous research. He found that the most fundamental factors are age and gender. The older a person is, the less willing he is to travel abroad. Also, men are more willing to travel abroad than the women.

Silventoinen et al. (2007) point out that overall life satisfaction in the home country has a direct impact on emigration tendencies. According to Diener, Suh and Oishi (1997) subjective well-being is understood as a multidimensional construct consisting of three separate components: (1) the presence of positive emotions, (2) the absence of negative emotions and (3) cognitive evaluation of life conditions (known as life satisfaction). Hřebíčková, et al. (2010) point out that this is a conscious assessment of one's own life, while the emotional dimension is a summary of moods and emotions, even at an unconscious level. Silventoinen et al. (2007) found that with increasing dissatisfaction with the living situation in their home country, there is an increasing tendency to emigrate. Other research has found that individuals with higher subjective well-being have lower international migration desires (Cai et. al., 2014). The same findings concerning Slovak students were presented in a study by Hajduch, Orosová \& Kulanová (2018). The authors confirmed that life satisfaction and emigration intentions are related. Indeed, university students who were characterized by lower life satisfaction showed stronger intentions to emigrate.

Like Slovakia, Americans have always been perceived as a society of migrants (Cooke, 2011). However, their migration rates are at record lows, with only $3.7 \%$ of Americans moving from one country to another. Cooke (2011) concludes that approximately $63 \%$ of this decline in the migration rate between 1999 and 2009 can be attributed to the 2007 economic crisis, a further $17 \%$ can be attributed to the demographic changes (e.g. population aging) and the remaining $20 \%$ to increased rootedness. He assumes that with the possible stability of housing markets and the effects of economic recovery, the migration rate will likely increase over several years although the long-term effects of the population aging and rootedness will keep the migration rate lower than otherwise.

In the current study, it was decided to explore this area and see if well-being is really such an important factor affecting the creation of emigration plans among university students or if rootedness can somehow affect this established relationship.

\section{Objectives}

The main objective of this study was to examine the relationship between emigration plans and well-being and rootedness. We also tested the psychological mechanism of this relationship, in terms of the mediation effect of rootedness in the relationship between well-being and emigration plans.

\section{Methods}

\subsection{Sample and procedure}

The data were collected via an online survey, as part of the Student Life Cohort Study (SLiCE 2016) which focuses on emigration/migration intentions and risk behavior of university students. Our research sample consisted of 141 (86.5\% female) Slovak university students; the mean age of the students was 22.5 years $(\mathrm{SD}=2.8)$. Based on their emigration plans, we divided the respondents into two groups, those who do not plan to leave Slovakia $(\mathrm{n}=77,54.6 \%, \mathrm{M}=22.9$ years, $\mathrm{SD}=3.1)$, and those who plan to leave Slovakia in the long term $(n=64,45.4 \%, M=22.1$ years, $S D=2.3)$.

\subsection{Measures}

All students were asked to fill in an online questionnaire, voluntarily and anonymously. For the purpose of this study, emigration plans and factors related to emigration plans were measured by the following:

- Emigration plans: were identified by one question:" Do you plan to leave Slovakia after you finish university" with 8 answer options: (1) No, I am not planning to leave; (2) I do not know, I have not thought about it; (3) I do not know, I have not decided yet; (4) I am planning to go abroad for six months; (5) I am planning to go abroad for six to twelve months; (6) I am planning to leave for more than a year; (7) I am planning to leave for more than five years; (8) I am planning to leave permanently. Based on the answer, the respondents were divided into two groups: (a) those who do not plan to leave Slovakia (answer 1); (b) those who plan to leave Slovakia in the long term (answer 6, 7 or 8). 
- Well-being: was addressed using the construct of subjective well-being which consists of a cognitive aspect in terms of life satisfaction (Diener et al, 1995) and experiencing positive and negative emotions (Dzuka \& Dalbet, 2002). Respondents were asked to indicate the extent to which they agreed with 5 statements (e.g."In most ways my life is close to my ideal." or "If I could live my life over, I would change almost nothing.") on a seven-point Likert scale ranging from 1 - strongly disagree to 7 - strongly agree. The score ranges from 5 to 35 points with a higher score indicating a higher level of well-being. Cronbach's alpha for well-being was 0.828 .

- Rootedness: was measured by the Rootedness scale (McAndrew, 1998) which assesses rootedness as a construct focusing on individual's psychological attachment to a place and social environment where one lives. The Rootedness scale captures this construct in two dimensions by focusing on the desire to change one's living environment ("Desire for change" subscale) and attachment to one's family and home ("Home/Family" subscale). Respondents were asked to indicate the extent to which they agreed with 6 statements for "Desire for change" subscale (e.g. " Moving from place to place is exciting and fun." or "I could not be happy living in one place for the rest of my life.") and with 4 statements for "Home/Family" subscale (e.g. "I am extremely satisfied with my present home." or "My family is very close-knit and I would be unhappy if I could not see them on a regular basis.") on a five-point Likert scale ranging from 1 - strongly disagree to 5 - strongly agree. The score ranges from 6 to 30 points for "Desire for change" subscale and from 4 to 20 points for the "Home/Family" subscale. A higher score for the "Desire for change", subscale indicates a higher level of a respondent's desire to change their living environment. Cronbach's alpha for this subscale was 0.528. A higher score for the "Home/Family", subscale indicates a higher level of a respondent's attachment to their family and home. Cronbach's alpha for this subscale was 0.604 .

\subsection{Statistical analyses}

A binary logistic regression analysis was applied in two steps. The first model was used to examine the relationship between well-being and emigration plans. In the second model, we added two dimensions of rootedness as independent variables. After using these regression models, we explored whether two dimensions of rootedness would mediate the relationship between well-being and emigration plans. For that we used The Hayes' PROCESS tool. All analyses were controlled for gender.

\section{Results}

The results showed that $54.6 \%$ of students in Slovakia (56.6\% female, $42.1 \%$ men) don't plan to leave Slovakia after they finish their studies and $45.4 \%$ of students ( $43.4 \%$ female, $57.9 \%$ men) plan to leave in the long term. The emigration plans among students with respect to gender can be seen in Table 1. There were no gender differences found in emigration plans. The descriptive analysis of all explored variables regarding emigration plans are presented in Table 2. In general, those who do not plan to leave Slovakia scored higher in well-being and family rootedness and lower in desire for change, compared to those who plan to leave Slovakia in the long term.

Table 1. Emigration plans among university students in Slovakia.

\begin{tabular}{|l|c|c|c|}
\hline \multicolumn{1}{|c|}{ Emigration plan } & $\begin{array}{c}\text { Among sample } \\
(\mathbf{n}=\mathbf{1 4 1})\end{array}$ & $\begin{array}{c}\text { Among female } \\
(\mathbf{n}=\mathbf{1 2 2})\end{array}$ & $\begin{array}{c}\text { Among men } \\
(\mathbf{n}=\mathbf{1 9})\end{array}$ \\
\hline Not planning to leave & $77(54.6 \%)$ & $69(56.6 \%)$ & $8(42.1 \%)$ \\
\hline Planning to leave in the long-term & $64(45.4 \%)$ & $53(43.4 \%)$ & $11(57.9 \%)$ \\
\hline
\end{tabular}

Table 2. Descriptive characteristics in the measured variables according to emigration plans.

\begin{tabular}{|l|c|c|c|c|}
\hline \multicolumn{1}{|c|}{ Variable } & $\begin{array}{c}\text { Theoretical } \\
\text { range }\end{array}$ & $\begin{array}{c}\text { Not planning to } \\
\text { leave }\end{array}$ & $\begin{array}{c}\text { Planning to leave in } \\
\text { the long-term }\end{array}$ & $\begin{array}{c}\text { T-test } \\
\text { value }\end{array}$ \\
\hline Well-being & $5-35$ & $\begin{array}{c}\mathrm{M}=17.84 \\
(\mathrm{SD}=3.78)\end{array}$ & $\begin{array}{c}\mathrm{M}=14.75 \\
(\mathrm{SD}=4.38)\end{array}$ & $4.497 * * *$ \\
\hline Rootedness - Desire for change & $6-30$ & $\begin{array}{c}\mathrm{M}=17.36 \\
(\mathrm{SD}=3.71)\end{array}$ & $\begin{array}{c}\mathrm{M}=22.31 \\
(\mathrm{SD}=3.30)\end{array}$ & $-8.275^{* * *}$ \\
\hline Rootedness - Home/Family & $4-20$ & $\begin{array}{c}\mathrm{M}=16.76 \\
(\mathrm{SD}=2.38)\end{array}$ & $\begin{array}{c}\mathrm{M}=14.42 \\
(\mathrm{SD}=3.03)\end{array}$ & $5.021^{* * *}$ \\
\hline
\end{tabular}

M-Mean; SD - Standard deviation; ${ }^{*} p<0.05, * * p<0.01, * * * p<0.001$ 
The first model explained $16.8 \%$ of the variance in emigration plans. As predicted, higher well-being was significantly associated with a lower probability of having emigration plans. Gender was not significant. For more details see Table 3.

In the second model, rootedness was added which then explained $51.6 \%$ of the variance in emigration plans. Two dimensions of rootedness were found to make the largest contribution in explaining emigration plans. Therefore, a greater desire for change was significantly associated with a higher probability of emigration plans while higher family rootedness was significantly associated with a lower probability of emigration plans. Interestingly, well-being was not shown to be a factor significantly related to emigration plans. Gender was not found to be significant either. For more details see Table 4.

Table 3. Regression model 1 -factors related to emigration plans among Slovak university students.

\begin{tabular}{|l|c|c|c|c|c|c|}
\hline \multicolumn{1}{|c|}{ Predictors } & \multirow{2}{*}{ B } & \multirow{2}{*}{ S. E. } & \multirow{2}{*}{$\operatorname{Exp}(\mathbf{B})$} & $\mathbf{9 5 \%}$ \% C. I for Exp(B) & \multirow{2}{*}{ Sig. } \\
\cline { 1 - 3 } & & & & Lower & Upper & \\
\hline Gender* & 0.108 & 0.543 & 1.114 & 0.385 & 3.226 & 0.843 \\
\hline Well-being & -0.183 & 0.048 & 0.833 & 0.758 & 0.914 & $<0.001$ \\
\hline
\end{tabular}

Note: * female as a reference group

Table 4. Regression model 2 - factors related to emigration plans among Slovak university students.

\begin{tabular}{|c|c|c|c|c|c|c|}
\hline \multicolumn{7}{|c|}{ Model $2\left(R^{2}=0.516\right)$} \\
\hline \multirow{2}{*}{ Predictors } & \multirow{2}{*}{ B } & \multirow{2}{*}{ S. E. } & \multirow{2}{*}{$\operatorname{Exp}(B)$} & \multicolumn{2}{|c|}{$95 \%$ C. I for $\operatorname{Exp}(B)$} & \multirow{2}{*}{ Sig. } \\
\hline & & & & Lower & Upper & \\
\hline Gender* & 0.102 & 0.666 & 1.108 & 0.301 & 4.082 & 0.878 \\
\hline Well-being & -0.072 & 0.061 & 0.931 & 0.826 & 1.049 & 0.239 \\
\hline Rootedness - Home/Family & -0.240 & 0.098 & 0.787 & 0.649 & 0.953 & $<0.05$ \\
\hline $\begin{array}{l}\text { Rootedness - Desire for } \\
\text { change }\end{array}$ & 0.367 & 0.073 & 1.444 & 1.252 & 1.666 & $<0.001$ \\
\hline
\end{tabular}

Note: * female as a reference group

These findings were confirmed by the mediation analysis. There was a significant indirect effect of well-being on emigration plans through rootedness - desire to change, $\mathrm{b}=-0.128$, BCa CI [- 0.240, - 0.064] and rootedness - family rootedness, $b=-0.068$, BCa CI [- 0.149, - 0.015]. Therefore, the association between well-being and emigration plans was fully mediated by two dimensions of rootedness. Our results also show that there are different psychological mechanisms. On one hand, the higher the well-being, the lower the desire for change and the lower the desire for change, the more likely it is that Slovak students will not plan to leave Slovakia. On the other hand, the higher the well-being, the higher the family rooting and the higher family rooting, the more likely it is that Slovak students will not plan to leave Slovakia. For a visualization and further details see Figure 1.

Figure 1. The mediation effect of rootedness in the relationship between well-being and emigration plans.

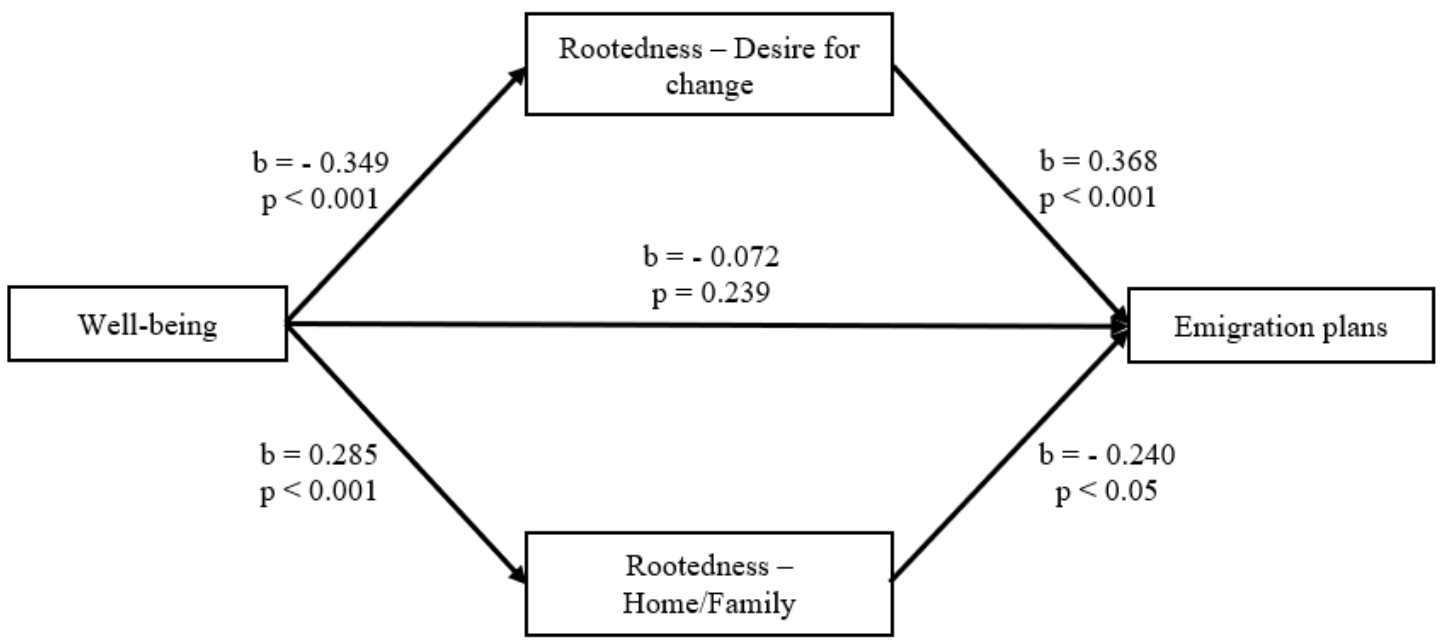




\section{Discussion and conclusions}

Although many theories of migration speak of the importance of economics and demographic factors in understanding migration behavior (Massey et. al., 1998) Cai et. al. (2014) point out that there may be something else that needs to be considered. Like many others (e.g. Silventoinen et al., 2007; Hajduch, Orosova and Kulan, 2018), these authors found out that people with higher well-being have a lower desire to emigrate. This is so because the relationship between subjective well-being and migration appears to be more robust then the income-migration relationship according to Cai et. al. (2014). Our results point to the fact that gender plays no role in developing emigration plans. However, it is of interest to see that well-being does not have to be as important in creating student emigration plans as previously thought, which is not in line with previous findings. Our research has shown that rootedness has a much greater impact on this process. Specifically, the high desire for change can encourage (despite high well-being) the creation of emigration plans, while high family rooting can prevent (despite low well-being) the creation of emigration plans. This is in line with Cook (2011) who found out that rootedness has an impact on migration in America.

The biggest limitation of this study concerns working with a small sample and also its gender imbalance. In this study we only focused on Slovak university students, so there is an opportunity to extend this research to university students in other countries, where we could also focus on the moderation effect of the country.

\section{Acknowledgements}

This work was supported by Research and Development support Agency under the contract No. APVV-15-0662.

\section{References}

Bahna, M. (2009). Pracovná migrácia zo Slovenska po vstupe do EÚ v kontexte krajín EÚ. Retrieved March 15, 2020, from: http://www.sociologia.sav.sk/publikacie.php?id=1216

Baláž, C. (2009). Súčasné migračné pohyby v kontexte Európskej únie a ich vzt’ah k Slovenskej republike. Parlamentný kuriér, 17 (171), 63-64.

Cai, R., Esipova, N. et. al. (2014). International Migration Desires Related to Subjective Well-Being. IZA Journal of Migration, 3 (8), 1-20.

Cooke, T.J. (2011). It is not just the economy: Declining migration and the rise of secular rootedness. Population, Space and Place, 17, 193-203.

Diener, E. D., Emmons, R. A., Larsen, R. J., and Griffin, S. (1985). The satisfaction with life scale. Journal of personality assessment, 49 (1), 71-75.

Diener, E., Suh, E. and Oishi, S. (1997). Recent findings on subjective well-being. Indian Journal of Clinical Psychology, 24, 25-41.

Džuka, J., Dalbert, C. (2002). Vývoj a overenie validity škály emocionálnej habituálnej subjektívnej pohody. Československá psychologie, 46 (3), 234-250.

Hajduch, B., Orosová, O. and Kulanová, M. (2018). Factors related to life satisfaction. Relationship between life satisfaction and emigration intentions among university students. In C. Pracana \& M. Wang (Eds.), Psychological Applications and Trends 2018, (177-181). Lisbon, Portuga: InScience Press.

Haluš, M., Hlaváč, M. et. al. (2017). Odliv mozgov po slovensky. Inštitútu finančnej politiky. Retrieved March 15, 2020, from http://www.finance.gov.sk/Default.aspx?CatID=11308

Hřebíčková, M. et. al. (2010). Osobnost jako prediktor osobní pohody v dospělosti. Československá psychologie, 54 (1), 31-41.

Káčerová, M., Horváthová, R. (2014). Zahraničná migrácia Slovenska - demografické a priestorové aspekty. Slovak Statistics and Demography, 2, 33-51.

Massey, D. S., Arango, J., Hugo, G., Kouaouchi, A., Pellegrino, A., and Taylor, J. E. (1998). Worlds in motion: Understanding international migration at the end of the millennium. Oxford, England: Clarendon Press.

McAndrew, F. T. (1998). The measurement of 'rootedness' and the prediction of attachment to home-towns in college students. Journal of Environmental Psychology, 18, 409-417.

Sheikh, A., Naqvi, S. H. A., Sheikh, K., Naqvi, S. H. S., and Bandukda, M. Y. (2012). Physician migration at its roots: a study on the factors contributing towards a career choice abroad among students at a medical school in Pakistan. Globalization and Health, 8 (43), 1-11.

Silventoinen, K. et. al. (2007). Selective international migration by social position, health behaviour and personality. European Journal of Public Health, 18 (2), 150-155. 